\title{
PERAN WORK LIFE BALANCE TERHADAP KINERJA KARYAWAN MELALUI KOMITMEN AFEKTIF SEBAGAI VARIABEL MEDIASI PADA KARYAWAN HOTEL BERBINTANG TIGA DI MAKASSAR, SULAWESI SELATAN
}

\author{
Evelyn Felicia Foanto ${ }^{1}$, Eugiena Brigitta Tunarso ${ }^{2}$, Endo Wijaya Kartika ${ }^{3 *}$ \\ ${ }^{1,2,3}$ Program Manajemen Perhotelan, Program Studi Manajemen, \\ Fakultas Bisnis dan Ekonomi, Universitas Kristen Petra \\ Jl. Siwalankerto 121-131, Surabaya, Indonesia \\ Email: evelynfoanto98@gmail.com; m33416089@john.petra.ac.id; endo@petra.ac.id \\ *Penulis korespondensi
}

\begin{abstract}
Abstrak
Industri perhotelan merupakan salah satu industri yang menerapkan jam kerja operasional 24 jam yang dapat memberikan dampak pada ketidakseimbangan pada kehidupan pribadi karyawan. Ketidakseimbangan antara pekerjaan dan kehidupan pribadi akan berdampak kepada komitmen organisasional karyawan terhadap organisasinya dan kemudian juga akan berdampak terhadap kinerja karyawan. Penelitian ini bertujuan untuk membuktikan secara empiris tentang peran work life balance terhadap komitmen afektif dan kinerja karyawan dalam konteks industri perhotelan di Indonesia. Sampel pada penelitian ini adalah 180 orang karyawan pada hotel berbintang tiga di kota Makassar, Sulawesi Selatan. Pengujian statistik menggunakan software SmartPLS 2.0, dan hasil penelitian membuktikan bahwa work life balance berpengaruh tetapi tidak signifikan terhadap kinerja karyawan, work life balance berpengaruh signifikan terhadap komitmen afektif, dan komitmen afektif berpengaruh signifikan terhadap kinerja karyawan.
\end{abstract}

Kata kunci: Work life balance; komitmen afektif; kinerja karyawan.

\begin{abstract}
Hospitality industry is one industry that applies 24-hour operational hours that could bring an impact on imbalances in employees' personal lives. The imbalance between work and personal life will also affect on employees' commitment towards their organization, and then it will also affect on employees' performance. This study aims to empirically investigate the role of work life balance on affective commitment and employees performance in the context of hospitality industry in Indonesia. The sample in this study was 180 employees who work at three-starred hotel in Makassar city, South Sulawesi. Statistical testing uses SmartPLS 2.0 software, and the results of the study prove that work life balance has an effect but not significantly on employees performance, work life balance affects on affective commitment significantly, and finally affective commitment affects significantly on employees performance.
\end{abstract}

Keywords: Work life balance; affective commitment; employees performance.

\section{PENDAHULUAN}

Saat ini karyawan yang bekerja di hotel cenderung menghadapi jam kerja yang panjang, serta tugas dan beban kerja yang berat. Hal ini memiliki dampak pada kehidupan pribadi karyawan, dimana karyawan akan sulit untuk menyeimbangkan antara kehidupan pribadi dan pekerjaan, terlebih ketika sebuah industri menerapkan jam kerja non-tradisional, dimana salah satunya adalah industri perhotelan (Suresh \& Begum, 2018). Hotel merupakan industri yang memiliki jam operasional kerja 24 jam, maka dari itu pihak hotel perlu untuk membuat pengaturan untuk menyeimbangkan kehidupan pribadi dan pekerjaan karyawan (Mohanty \& Mohanty, 2014).
Keseimbangan peran antara kehidupan keluarga dan pekerjaan dikenal dengan istilah work life balance. Guest (2002) menyatakan bahwa work life balance adalah kemampuan karyawan untuk mengatur antara pekerjaan dan kehidupan keluarganya. Isu work life balance ini sering kali terjadi pada karyawan dalam lingkup pekerjaan apa saja, hal ini disebabkan karena para karyawan tidak hanya menuntut pekerjaan, akan tetapi juga menuntut kesejahteraan (Chaitra, Kumar \& Murthy, 2016). Maka dari itu, organisasi harus melakukan langkah-langkah kebijakan yang bertujuan untuk menyejahterakan para karyawannya, misalnya dengan cara memberikan kesempatan kepada karyawan untuk menghabiskan waktu bersama keluarganya melalui kegiatan yang 
diadakan oleh organisasi seperti family gathering, dan organisasi juga harus dapat bekerjasama dan mendukung karyawan dalam menyusun strategi untuk membantu mencapai keseimbangan antara kehidupan keluarga dan pekerjaannya (Sivaraman, 2016).

Ketika seseorang karyawan memutuskan untuk bekerja, secara langsung karyawan tersebut akan terikat dengan perusahaan, sehingga para karyawan yang telah memutuskan untuk bekerja akan memiliki sebuah tanggung jawab pada perusahaan yang tidak dapat ditinggalkan. Selain itu, para karyawan harus siap untuk menghadapi sebuah tuntutan pekerjaan yang banyak. Tuntutan pekerjaan inilah yang akan menyebabkan karyawan kesulitan untuk menyeimbangkan antara kehidupan pribadi dan kehidupan pekerjaannya. Ketika kehidupan pribadi dan pekerjaan tidak seimbang, hal itu akan menimbulkan stres, konflik yang mengakibatkan para karyawan harus memutuskan tetap bekerja dan mengorbankan keluarga atau keluar dari pekerjaan dan bersama keluarganya.

Ketidakseimbangan antara pekerjaan dan kehidupan pribadi akan berdampak kepada komitmen organisasional karyawan terhadap organisasinya. Lee \& Reade (2018) mengatakan bahwa komitmen organisasional merupakan keinginan dari karyawan itu sendiri untuk mengabdi pada suatu organisasi. Apabila karyawan tidak dapat menyeimbangkan kehidupan pribadi dengan kehidupan kerjanya, hal ini dapat memberikan dampak yang buruk terhadap komitmen yang dimiliki karyawan tersebut terhadap organisasinya, begitu juga sebaliknya. Hal ini didukung oleh studi dari Riffay (2019) yang menyatakan bahwa peningkatan work life balance akan juga meningkatkan komitmen organisasional. Salah satu dimensi komitmen organisasional yang dianggap penting untuk dimiliki oleh setiap karyawan dalam organisasi adalah komitmen afektif, dimana merupakan sebuah ikatan emosional karyawan dengan organisasi, yang membuat karyawan merasa nyaman dengan pekerjaannya saat ini sehingga memutuskan untuk tetap bertahan dalam organisasi (Meyer \& Allen, 1991).

Terciptanya work life balance dan komitmen afektif akan dapat juga berdampak pada peningkatan atau penurunan kinerja karyawan. Keseimbangan antara kehidupan pribadi dan pekerjaan perlu diupayakan terjadi agar karyawan dapat bekerja secara maksimal, sehingga apabila kehidupan pribadi dan pekerjaan tidak seimbang akan tercipta stres dan tekanan dalam diri karyawan yang berakibat pada penurunan produktivitas kerja (Aslam, 2015). Mendis \& Weerakkody (2017) menyatakan bahwa untuk dapat memberikan kinerja yang maksimal karyawan perlu untuk merasa bahagia dan salah satu sumber kebahagiaan karyawan adalah dari keluarga dan kehidupan pribadi. Maka dari itu work life balance harus diseimbangkan untuk mendukung karyawan dalam bekerja secara maksimal.

Beberapa studi sebelumnya terkait peran work life balance terhadap komitmen organisasional telah dilakukan di luar negeri misalnya studi dari Oyewobi, Oke, Adeneye, \& Jimoh (2019); dan Arif \& Farooqi (2014), maupun secara khusus dilakukan di Indonesia misalnya studi dari Riffay (2019); Rini \& Indrawati (2019); Jainudin, Ikhram, \& Hardiyono (2019); Rene \& Wahyuni (2018); serta Sabijono, Saerang, \& Tumewu (2017). Akan tetapi berdasarkan studi-studi yang pernah dilakukan sebelumnya masih menyisakan inkonsistensi hasil temuan studi yang masih bertolak belakang. Seperti misalnya Riffay (2019) dan Rini \& Indrawati (2019) membuktikan bahwa work life balance memberikan dampak terhadap terciptanya komitmen organisasional, sedangkan hasil studi lainnya membuktikan bahwa work life balance tidak memberikan dampak terhadap peningkatan maupun penurunan komitmen organisasional (Rene \& Wahyuni, 2018). Inkonsistensi hasil studi tersebut yang kemudian mendorong untuk dilakukannya studi empiris tambahan untuk membuktikannya. Terlebih beberapa studi sebelumnya yang dilakukan di Indonesia, masih sedikit yang melakukannya secara spesifik di kota Makassar kecuali studi dari Jainudin et al. (2019) akan tetapi sama sekali masih belum pernah dilakukan dalam konteks industri perhotelan.

Studi sebelumnya juga membuktikan bahwa work life balance memberikan dampak terhadap kinerja karyawan, maupun komitmen organisasional terhadap kinerja karyawan (Mendis \& Weerakkody, 2017; Ramli, 2017; Dinc, 2017; dan Aslam, 2015). Akan tetapi studi-studi tersebut masih belum pernah dilakukan terkait ketiganya secara spesifik terhadap komitmen afektif dan secara khusus dalam konteks industri perhotelan di Indonesia. Oleh karena itu studi ini dilakukan untuk melakukan pembuktian empiris terkait peran work life balance terhadap komitmen afektif dan kinerja karyawan dalam konteks karyawan pada industri perhotelan secara khusus di kota Makassar, Sulawesi Selatan.

\section{TINJAUAN PUSTAKA}

\section{Work Life Balance}

Chaitra et al. (2016) menyatakan bahwa work life balance mengacu pada sejauh mana seorang 
karyawan dapat terlibat dan secara bersamaan juga merasa puas atas peran pekerjaan dan peran keluarga dalam kehidupan karyawan tersebut. Work life balance adalah interaksi antara pekerjaan dan kegiatan lain yang mencakup keluarga, komunitas, waktu luang dan pengembangan pribadi. Work life balance bukan hanya mengenai keluarga seperti misalnya mengurus anak, akan tetapi bukan juga mengenai bekerja dengan jam kerja yang lebih sedikit, namun ini mengenai bekerja secara "smart", dimana karyawan harus memberikan apa yang dibutuhkan dalam hal pekerjaan dan juga keluarga tanpa membahayakan atau mengorbankan satu sama lain. Hal ini dapat mengurangi stres dan ketidakhadiran dalam suatu organisasi, sehingga karyawan dapat bekerja dengan produktivitas yang tinggi (Mendis \& Weerakkody, 2017).

Oyewobi et al. (2019) menyatakan bahwa terdapat beberapa hal yang perlu diperhatikan supaya work life balance dapat berjalan dengan baik bagi karyawan, antara lain sebagai berikut:

1. Karyawan memiliki dukungan dari pihak luar dimana dukungan dari pihak luar dapat berasal dari keluarga atau teman selain rekan kerja. Dukungan dari pihak luar akan membantu meningkatkan semangat kerja sehingga memberikan keseimbangan antara pekerjaan dengan kehidupan pribadi. Lingard, Francis, \& Turner (2010) menjelaskan bahwa bentuk dukungan dari pihak luar contohnya adalah dari keluarga. Keluarga adalah pihak yang dapat memberikan semangat kepada karyawan, terutama ketika karyawan menceritakan persoalannya kepada keluarga di rumah.

2. Karyawan perlu memiliki waktu yang cukup untuk dapat terlibat menghabiskan waktu bersama keluarga, kerabat, ataupun sahabat (Francis, Lingard, \& Gibson, 2006). Seringkali karyawan yang terlalu sibuk dengan pekerjaannya sulit untuk memiliki waktu diluar pekerjaannya. Hal ini akan berdampak terhadap penurunan kualitas kehidupan sosial karyawan dan mengarah ketidakstabilan work life balance.

3. Karyawan perlu untuk merasa benar-benar menikmati waktu yang dihabiskan bersama keluarga dan teman diluar pekerjaan (Francis et al., 2006). Untuk menciptakan kestabilan pekerjaan dan kehidupan pribadi, tidak cukup bagi karyawan hanya berkumpul bersama keluarga atau teman akan tetapi perlu untuk benar-benar memiliki kualitas dan waktu yang diperlukan.

4. Karyawan perlu merasa puas dengan hubungan yang dimiliki saat ini dengan orang-orang penting dan terdekat dalam hidupnya seperti bersama keluarga, kerabat, maupun sahabat. Lingard \& Francis (2004) menyatakan bahwa kepuasan yang dirasakan karyawan dapat dinilai misalnya melalui sejauh mana perasaan yang timbul atas kehidupan pernikahan yang dirasakan apakah membahagiakan atau tidak, atau misalnya dengan adanya kepuasan yang muncul atas kebanggan menjadi orang tua yang baik bagi anak-anaknya.

5. Karyawan perlu memiliki kegiatan atau aktivitas yang dapat memberikan ketenangan dan kedamaian seperti beribadah, relaksasi, dimana karyawan dapat memperoleh ketenangan setelah melakukan kegiatan tersebut. Kegiatan ini juga akan membantu karyawan untuk mengalihkan perhatiannya dari pekerjaan sehingga dapat menciptakan keseimbangan antara pekerjaan dan kehidupan pribadi yang lebih baik (Simmons, 2012).

6. Kehidupan seorang karyawan bukan hanya tentang pekerjaan, terkadang orang-orang diluar konteks pekerjaan seperti keluarga teman, dan orang lain yang juga membutuhkan bantuan dari karyawan tersebut. Jika seorang karyawan dapat meluangkan waktunya untuk membantu orang lain seperti keluarganya atau orang di luar keluarga yang mengalami persoalan diluarkonteks pekerjaan maka hal tersebut dapat meningkatkan kualitas kehidupan sosial dan menghadirkan perasaan senang (Sturges \& Guest, 2004).

7. Karyawan dapat tetap memegang kendali akan hal-hal penting dalam hidupnya. Ketika pekerjaan mengambil alih hidup seseorang maka kecenderungan yang terjadi adalah karyawan tersebut tidak lagi dapat menguasai kehidupannya dan tidak lagi mampu memegang kendali akan hal-hal penting dalam hidupnya. Hal ini mengakibatkan terjadinya penurunan kualitas work life balance.

8. Karyawan harus dapat mengatur tanggung jawab pekerjaannya tanpa harus mengorbankan keinginan pribadinya. Karyawan harus dapat mengatur tanggung jawab pekerjaannya tanpa tanpa harus mengorbankan keinginan pribadinya. Karyawan harus benar-benar dapat menyelesaikan pekerjaan di kantor tanpa terganggu oleh persoalan yang terjadi di rumah. Ketika karyawan dapat mengelola tanggung jawab pekerjaan dan keinginan pribadinya dengan efektif maka hal itu akan meningkatkan work life balance (Lingard, Brown, Bradley, Bailey, \& Townsend, 2007). 
9. Ketika berada di rumah karyawan sebaiknya tidak perlu merasa khawatir terhadap masalah pekerjaan, kekhawatiran ini bisa muncul ketika karyawan di kejar oleh deadline yang diberikan oleh perusahaan sehingga karyawan dituntut untuk terus bekerja sehingga menyebabkan keluarga menjadi terbengkalai. Hal ini dapat menurunkan keseimbangan pekerjaan dan kehidupan pribadi.

10. Dalam pekerjaan karyawan harus bertanggung jawab dan profesional sehingga kekhawatiran tentang masalah personal harus dikesampingkan saat bekerja. Kekhawatiran yang terjadi pada karyawan dapat menyebabkan tidak fokus dan menurunkan keseimbangan kehidupan karyawan tersebut.

11. Karyawan perlu untuk merasa puas dengan kehidupan yang terjadi di luar pekerjaannya. Kepuasan dapat ditimbulkan karena karyawan masih ada waktu luang untuk menikmati kehidupan di luar perkerjaanya seperti dengan melakukan aktivitas olahraga atau melakukan hobi apapun yang dapat membantu karyawan sehingga tidak hanya berpikir mengenai $\mathrm{p}$ ekerjaannya (Lingard \& Francis, 2004).

\section{Komitmen Afektif}

Menurut Meyer et al., (1991) komitmen afektif mengacu pada ikatan emosional dengan organisasi, dimana karyawan merasa nyaman dengan pekerjaannya saat ini sehingga memutuskan untuk menetap di perusahaan tersebut. Karyawan dengan komitmen afektif yang kuat akan tetap berada didalam sebuah organisasi karena keinginannya sendiri. Komitmen afektif seorang karyawan dapat dipengaruhi dengan pengalamannya selama berada di organisasi. Karyawan dengan pengalaman kerja yang memuaskan akan cenderung meningkatkan atau mengembangkan keterikatan afektif yang lebih kuat terhadap organisasi daripada karyawan yang memiliki pengalaman yang kurang memuaskan terhadap organisasi.

Komitmen afektif merupakan dimensi komitmen yang paling kuat dan konsisten jika dikaitkan dengan kinerja karyawan. Saygan (2011) menambahkan bahwa karyawan tidak pernah berkomitmen secara emosional pada organisasi, tetapi karyawan tetap bekerja karena karyawan tidak ingin kehilangan status jabatan dan gajinya. Oleh karena itu penting bagi suatu perusahaan untuk dapat menumbuhkan komitmen afektif karyawannya, karena dengan memiliki komitmen afektif maka karyawan akan bersedia untuk berkomitmen pada perusahaan tanpa dipengaruhi oleh gaji atau penghargaan yang diberikan perusahaaan dan akan bersedia untuk memberikan kinerja yang terbaik.

\section{Kinerja Karyawan}

Dinc (2017) menyatakan bahwa kinerja karyawan berkaitan erat dengan hasil kerja karyawan mengacu kepada tujuan organisasi yang diukurkan dengan evaluasi kinerja berhubungan dengan tugastugas pekerjaan, serta kinerja juga berkaitan dengan kemampuan karyawan untuk menyelesaikan tugastugasnya secara efisien.

Kinerja dapat meliputi dua dimensi pengukuran yaitu task performance dan contextual performance. Task performance mengacu kepada karyawan melakukan segala aktivitas pekerjaan yang berkaitan dengan kinerja individu yang akan memberikan dampak terhadap organisasi, yang meliputi tugastugas organisasi dan prosedur yang harus dipatuhi. Task performance berkaitan dengan penggunaan keterampilan teknis dan pengetahuan karyawan yang diperlukan untuk pekerjaan yang dilakukan, dan merupakan persyaratan formal pekerjaan karyawan yang tercantum dalam deskripsi pekerjaan karyawan (Scotter, Motowidlo, \& Cross, 2000).

Contextual performance berkaitan dengan kemampuan antar personal karyawan untuk berinteraksi dengan orang lain seperti rekan kerja, menjadi pendengar yang baik, serta mampu bekerjasama dalam tim dengan baik. Sehingga kemampuan ini dibutuhkan karyawan untuk memelihara dan meningkatkan hubungan sosial dalam suatu organisasi untuk mendukung tugas-tugas yang perlu dilakukan karyawan. Seringkali kemampuan ini tidak secara implisit tertulis dalam deskripsi pekerjaan secara resmi akan tetapi dianggap sebagai komponen penting bagi kinerja karyawan secara keseluruhan (Scotter et al., 2000).

\section{Work Life Balance dan Kinerja Karyawan}

Ketidakseimbangan antara kehidupan pribadi dan pekerjaan akan menciptakan stres dalam diri karyawan yang dapat berdampak kepada penurunan produktivitas kerja karyawan (Aslam, 2015). Sebaliknya ketika kehidupan pribadi karyawan dan pekerjaannya seimbang, karyawan akan cenderung lebih fokus, memiliki perasaan yang positif, dan tidak mengalami stres sehingga dedikasi yang diberikan kepada pekerjaan akan semakin baik dan juga berdampak terhadap peningkatan kinerja yang ditunjukkan oleh karyawan (Mendis \& Weerakkody, 
2017). Hasil studi sebelumnya juga mendukung bahwa work life balance berdampak signifikan terhadap kinerja karyawan (Mendis \& Weerakkody, 2017; Aslam, 2015). Oleh karena itu:

$\mathrm{H1}$ : Work life balance berpengaruh signifikan terhadap kinerja karyawan

\section{Work Life Balance dan Komitmen Afektif}

Ketika keseimbangan antara kehidupan pekerjaan dan pribadi karyawan terjadi, akan ada kecenderungan bagi karyawan untuk lebih fokus terhadap pekerjaannya, menimbulkan perasaan senang dan positif dalam menjalankan pekerjaannya (Riffay, 2019). Hal ini dapat memberikan persepsi positif dari karyawan bahwa organisasi menyediakan kesempatan bagi karyawan untuk memenuhi kebutuhan pribadinya selain hanya menuntut kewajiban karyawan atas pekerjaannya. Persepsi positif tersebutlah yang membentuk ikatan emosional karyawan bahwa organisasi peduli atas keseimbangan kehidupan dan pekerjaan karyawan. Maka dari itu semakin seimbang kehidupan pribadi dan pekerjaan karyawan maka dapat meningkatkan komitmen afektif karyawan. Studi empiris sebelumnya turut mendukung bahwa work life balance dapat berpengaruh secara signifikan terhadap komitmen afektif karyawan (Oyewobi et al., 2019; Riffay, 2019; Rini \& Indrawati, 2019; Jainudi et al., 2019; dan Arif \& Farooqi, 2014). Maka dari itu:

$\mathrm{H} 2$ : Work life balance berpengaruh signifikan terhadap komitmen afektif

\section{Komitmen Afektif dan Kinerja Karyawan}

Karyawan yang memiliki dedikasi pada organisasinya akan memberikan respon yang positif dengan melakukan tugas-tugasnya secara seksama dan maksimal. Ketika karyawan merasa memiliki ikatan emosional dan memiliki tujuan yang sama dengan organisasi, maka karyawan tersebut akan memberikan usaha terbaiknya untuk mencapai tujuan bersama tersebut. Usaha maksimal tersebut akan tercermin dalam pengerjaan tugas-tugas yang diberikan oleh organisasi (Ramli, 2019). Karyawan yang memiliki komitmen afektif yang kuat akan terus bekerja di suatu organisasi karena keinginannya sendiri, dimana karyawan akan merasa bangga dengan organisasinya dan berusaha untuk selalu melakukan yang terbaik bagi organisasi (Saygan, 2011). Hasil studi empiris yang pernah dilakukan membuktikan bahwa komitmen afektif dapat berpengaruh secara signifikan terhadap kinerja karyawan (Ramli, 2019; Dinc, 2017; Saygan, 2011). Oleh karena itu:

H3: Komitmen afektif berpengaruh signifikan terhadap kinerja karyawan

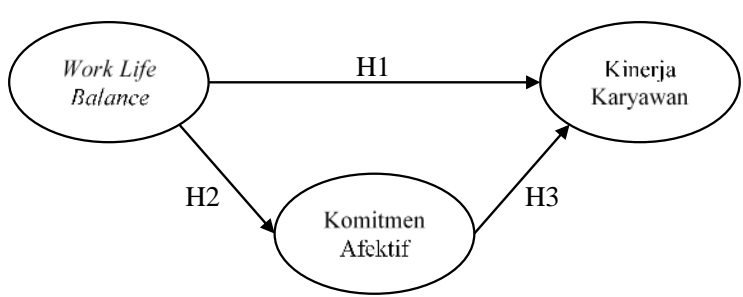

Gambar 1. Model Penelitian

\section{METODE PENELITIAN}

Penelitian ini adalah penelitian kuantitatif dimana berfokus kepada penelitian ilmiah yang sistematis atas fenomena-fenomena yang terjadi beserta hubungannya melalui penghitungan angka yang berasal dari sampel responden sebagai tanggapan atas fenomena yang terjadi. Pada penelitian ini terdapat satu variabel eksogen, satu variabel endogen, dan satu variabel endogen perantara. Variabel eksogen pada penelitian ini adalah work life balance (X1), sedangkan variabel endogen adalah kinerja karyawan (Y), dan variabel endogen perantara adalah komitmen afektif (Z).

Populasi pada penelitian ini adalah karyawan tetap pada hotel berbintang tiga di kota Makassar, Sulawesi Selatan dengan total populasi yang diketahui adalah 279 karyawan yang berasal dari empat hotel antara lain hotel D'Maleo, hotel Swiss-Belinn, hotel M Regency, dan hotel Ramedo. Pengambilan sampel berdasarkan populasi menggunakan "10times rule of thumb" sebagai penghitungan sampel minimal menggunakan structural equational modeling (Hair, Sarstedt, Ringle, \& Mena, 2012). Penghitungan sampel adalah 10 kali dari jumlah maksimal jalur yang mengarah pada variabel laten dalam model SEM. Pada model penelitian ini terdapat tiga jalur sehingga jumlah minimal sampel yang digunakan adalah 30 orang responden, dan pada penelitian ini total sampel yang digunakan adalah 180 orang karyawan yang bekerja pada hotel berbintang tiga di kota Makassar, Sulawesi Selatan.

Penggunaan indikator pada variabel work life balance diadopsi dari indikator-indikator studi yang telah dilakukan oleh Oyewobi et al. (2019); Lingard et al. (2007); dan Francis et al. (2006) dengan total 11 butir indikator pengukuran. Indikator untuk variabel komitmen afektif diadopsi dari Sukamto, Junarto, Kaihatu, \& Kartika (2014) dengan menggunakan 8 butir indikator pengukuran. Sedangkan indikator untuk variabel kinerja karyawan diadopsi dari studi Lin, Lamond, Yang, \& Hwang (2014) yang terdiri dari 16 butir indikator pengukuran. Pengukuran kuesioner penggunakan skala Likert 1 sampai 5 untuk pengukuran persetujuan, dengan 1 merupakan sangat tidak setuju dan 5 merupakan sangat setuju. 


\section{HASIL PENELITIAN DAN PEMBAHASAN}

Tahapan pertama yang dilakukan untuk pengujian statistik adalah dengan melakukan pengujian validitas dan reliabilitas, dan kemudian dilanjutkan dengan pengujian hipotesis dengan bantuan software SmartPLS 2.0 sebagai media pengukuran statistik. Pengujian validitas dilakukan dengan mengukur nilai loading factor pada masing-masing variabel manifes dengan batas minimal nilai untuk dapat dikategorikan valid adalah lebih besar dari 0,5 untuk dapat dianggap cukup mewakili variabel laten.

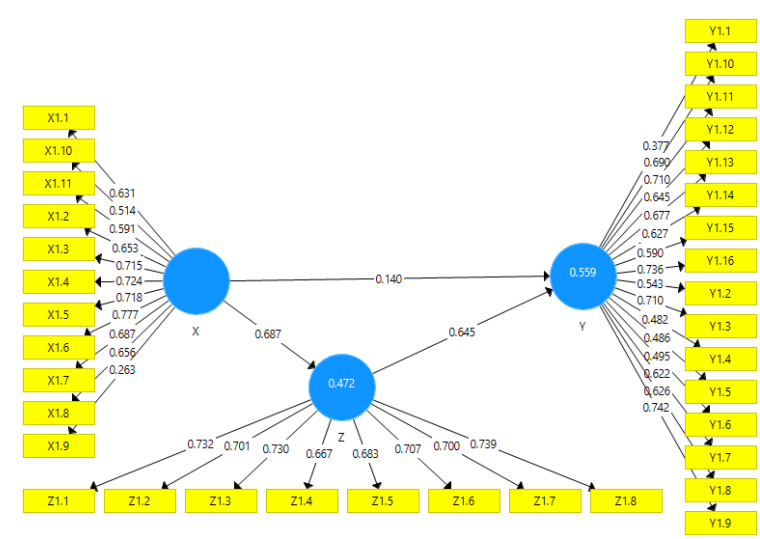

Gambar 2. Tahap Pertama Validitas Konvergen

Berdasarkan gambar 2, dapat diketahui bahwa terdapat lima indikator yang tidak memenuhi persyaratan minimal nilai loading factor, sehingga indikator tersebut akan dihilangkan dari model dan tidak diikutkan dalam penghitungan selanjutnya. Gambar 3, menunjukkan tahap kedua pengukuran validitas konvergen dengan seluruh indikator telah memenuhi persyaratan validitas.

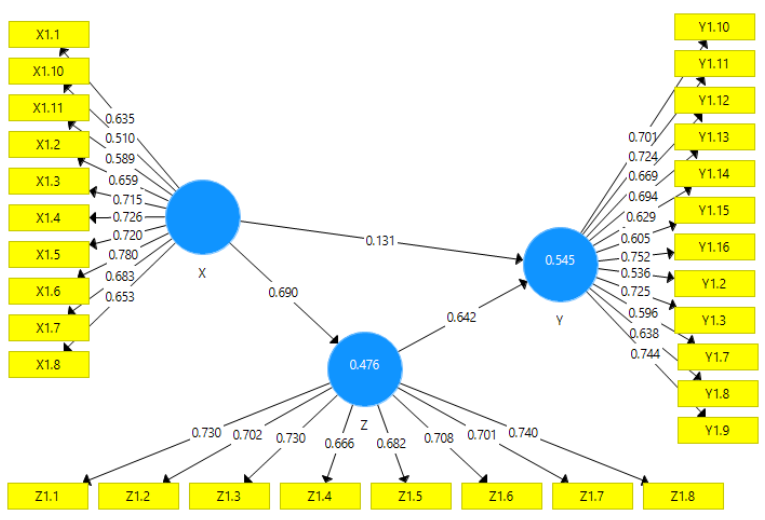

Gambar 3. Tahap Kedua Validitas Konvergen

Pengukuran validitas selanjutnya adalah mengukur validitas diskriminan yaitu dengan melihat cross loading pengukuran indikator terhadap variabel latennya. Apabila nilai korelasi antara indikator dengan variabel laten aslinya lebih tinggi daripada korelasi indikator dengan variabel laten lainnya maka dapat dikatakan valid secara diskriminan.

Tabel 1. Nilai Cross Loading

\begin{tabular}{cllll}
\hline $\begin{array}{c}\text { Indika- } \\
\text { tor }\end{array}$ & Balance & Afektif & $\begin{array}{c}\text { Kinerja } \\
\text { Karyawan }\end{array}$ & Keterangan \\
\hline X1.1 & $\mathbf{0 , 6 3 5}$ & 0,359 & 0,315 & Valid \\
X1.2 & $\mathbf{0 , 6 5 9}$ & 0,346 & 0,343 & Valid \\
X1.3 & $\mathbf{0 , 7 1 5}$ & 0,434 & 0,345 & Valid \\
X1.4 & $\mathbf{0 , 7 2 6}$ & 0,463 & 0,408 & Valid \\
X1.5 & $\mathbf{0 , 7 2 0 0 0}$ & 0,5 & 0,342 & Valid \\
X1.6 & $\mathbf{0 , 7 8}$ & 0,547 & 0,426 & Valid \\
X1.7 & $\mathbf{0 , 6 8 3}$ & 0,396 & 0,414 & Valid \\
X1.8 & $\mathbf{0 , 6 5 3}$ & 0,5 & 0,378 & Valid \\
X1.10 & $\mathbf{0 , 5 1}$ & 0,499 & 0,425 & Valid \\
X1.11 & $\mathbf{0 , 5 8 9}$ & 0,492 & 0,4 & Valid \\
Z1.1 & 0,551 & $\mathbf{0 , 7 3}$ & 0,56 & Valid \\
Z1.2 & 0,552 & $\mathbf{0 , 7 0 2}$ & 0,507 & Valid \\
Z1.3 & 0,5 & $\mathbf{0 , 7 3}$ & 0,558 & Valid \\
Z1.4 & 0,429 & $\mathbf{0 , 6 6 6}$ & 0,497 & Valid \\
Z1.5 & 0,537 & $\mathbf{0 , 6 8 2}$ & 0,443 & Valid \\
Z1.6 & 0,488 & $\mathbf{0 , 7 0 8}$ & 0,53 & Valid \\
Z1.7 & 0,405 & $\mathbf{0 , 7 0 1}$ & 0,506 & Valid \\
Z1.8 & 0,421 & $\mathbf{0 , 7 4}$ & 0,537 & Valid \\
Y1.2 & 0,296 & 0,34 & $\mathbf{0 , 5 3 6}$ & Valid \\
Y1.3 & 0,43 & 0,507 & $\mathbf{0 , 7 2 5}$ & Valid \\
Y1.7 & 0,391 & 0,442 & $\mathbf{0 , 5 9 6}$ & Valid \\
Y1.8 & 0,333 & 0,427 & $\mathbf{0 , 6 3 8}$ & Valid \\
Y1.9 & 0,436 & 0,548 & $\mathbf{0 , 7 4 4}$ & Valid \\
Y1.10 & 0,464 & 0,608 & $\mathbf{0 , 7 0 1}$ & Valid \\
Y1.11 & 0,408 & 0,5 & $\mathbf{0 , 7 2 4}$ & Valid \\
Y1.12 & 0,354 & 0,46 & $\mathbf{0 , 6 6 9}$ & Valid \\
Y1.13 & 0,392 & 0,518 & $\mathbf{0 , 6 9 4}$ & Valid \\
Y1.14 & 0,32 & 0,462 & $\mathbf{0 , 6 2 9}$ & Valid \\
Y1.15 & 0,232 & 0,421 & $\mathbf{0 , 6 0 5}$ & Valid \\
Y1.16 & 0,486 & 0,581 & $\mathbf{0 , 7 5 2}$ & Valid \\
\hline & & & & \\
\hline
\end{tabular}

Dengan melihat tabel 1, dapat dikatakan bahwa keseluruhan indikator memiliki korelasi yang lebih besar terhadap variabel laten aslinya sehingga secara diskriminan dapat dikatakan bahwa indikatorindikator tersebut adalah valid. Pengujian selanjutnya adalah melakukan uji reliabilitas yaitu dengan melihat nilai composite reliability dan cronbach's alpha dibandingkan dengan nilai minimal untuk dapat dikategorikan reliabel yaitu lebih besar dari 0,6. Tabel 2, menunjukkan bahwa seluruh nilai reliabilitas variabel lebih besar dari 0,6 sehingga seluruh variabel dalam model penelitian ini dapat dikatakan reliabel.

Tabel 2. Uji Reliabilitas

\begin{tabular}{ccc}
\hline & Cronbach's Alpha & Composite Reliability \\
\hline $\mathbf{X}$ & 0,862 & 0,89 \\
$\mathbf{Y}$ & 0,888 & 0,907 \\
$\mathbf{Z}$ & 0,858 & 0,889 \\
\hline
\end{tabular}


Proses pengukuran selanjutnya adalah melakukan pengujian hipotesis dari model penelitian yang telah diajukan. Hipotesis yang diajukan dapat dikategorikan didukung apabila pengaruh antara dua variabel adalah signifikan terlepas dari apapun arah dari pengaruh tersebut. Pengukuran signifikansi adalah dengan melihat nilai T-statistik pada hasil pengolahan statistik seperti yang tertera pada tabel 3, dimana nilai T-statistik dibandingkan dengan 1,96 sebagai nilai minimal untuk dapat dianggap signifikan. Berdasarkan tabel 3 tersebut dapat diketahui bahwa hipotesis 1 tidak didukung, sedangkan hipotesis 2 dan 3 didukung.

Tabel 3. Uji Hipotesis

\begin{tabular}{cccccc}
\hline $\begin{array}{c}\text { Hipo- } \\
\text { tesis }\end{array}$ & $\begin{array}{c}\text { Pengaruh } \\
\text { Langsung }\end{array}$ & $\begin{array}{c}\text { Koefisien } \\
\text { Path }\end{array}$ & $\begin{array}{c}\text { Standard } \\
\text { Error }\end{array}$ & $\begin{array}{c}\text { T- } \\
\text { Statistic }\end{array}$ & $\begin{array}{c}\text { Keterang- } \\
\text { an }\end{array}$ \\
\hline H1 $\begin{array}{l}\text { Work Life } \\
\text { Balance }(\mathrm{X}) \\
\rightarrow \text { Kinerja }\end{array}$ & 0,131 & 0,075 & 1,756 & $\begin{array}{c}\text { Tidak } \\
\text { Signifikan }\end{array}$ \\
& $\begin{array}{l}\text { Karyawan } \\
(\text { Y) }\end{array}$ & & & & \\
& $\begin{array}{l}\text { Work Life } \\
\text { H2 } \begin{array}{l}\text { Balance } \\
\text { (X) } \rightarrow\end{array}\end{array}$ & 0,69 & 0,044 & 15,704 & Signifikan \\
& $\begin{array}{l}\text { Komitmen } \\
\text { Afektif (Z) }\end{array}$ & & & & \\
& & & & \\
Komitmen & & & & \\
Afektif (Z) & 0,642 & 0,076 & 8,455 & Signifikan \\
& $\begin{array}{l}\rightarrow \text { Kinerja } \\
\text { Karyawan } \\
\text { (Y) }\end{array}$ & & & & \\
\hline
\end{tabular}

Hasil penelitian ini membuktikan bahwa work life balance masih belum cukup mampu menjelaskan pengaruhnya terhadap kinerja karyawan. Hasil penelitian ini turut mendukung studi yang pernah dilakukan oleh Krishnan, Loon, \& Tan (2018) serta Kim (2014) yang juga membuktikan bahwa work life balance belum cukup mampu menjelaskan pengaruhnya terhadap kinerja karyawan. Dari sudut pandang organisasi seringkali organisasi menuntut karyawannya untuk bekerja secara profesional tanpa memperhatikan keseimbangan antara kehidupan pribadi dan pekerjaannya, sehingga karyawan harus tetap berusaha untuk menunjukkan kinerja yang terbaik (Fidyani \& Prasetya, 2018). Sehingga terlepas dari seimbang atau tidak kinerja yang ditunjukkan harus selalu maksimal. Saat karyawan mengalami tidakseimbangan antara kehidupan pribadi dan pekerjaan, karyawan tidak boleh melampiaskannya di tempat kerja dengan bekerja asal-asalan, karena di tempat kerja tentunya ditetapkan prosedur dan peraturan yang mengikat. Setiap pekerjaan yang dilakukan tidak akan lepas dari evaluasi sehingga karyawan harus bersungguh-sungguh dalam bekerja apabila tidak ingin memperoleh penilaian buruk. Hasil evaluasi yang buruk akan berdampak buruk seperti peringatan keras, pemotongan bayaran, bahkan sampai pemecatan. Maka dari itu karyawan perlu selalu mempertimbangkan konsekuensi tersebut dan mau tidak mau harus tetap berusaha menunjukkan kinerja yang terbaik.

Work life balance pada penelitian ini terbukti dapat meningkatkan komitmen afektif karyawan, sehingga semakin seimbang antara pekerjaan dan kehidupan pribadi akan semakin meningkatkan komitmen afektif. Hasil ini turut mendukung studi empiris sebelumnya (Oyewobi et al., 2019; Riffay, 2019; Rini \& Indrawati, 2019; Jainudi et al., 2019; dan Arif \& Farooqi, 2014). Semakin seimbang kehidupan yang dimiliki karyawan antara pekerjaan dan kehidupan pribadi maka hal tersebut akan membuat karyawan dapat lebih berpikir jernih. Hal ini didukung dengan adanya kebijakan organisasi yang menghubungkan karyawan dalam menyeimbangkan kehidupan pribadi dan pekerjaan, sehingga karyawan merasa cocok dengan organisasinya. Teori pertukaran sosial menekankan kepada adanya efek timbal balik, dimana karyawan akan membalas kebaikan yang telah dilakukan oleh organisasi karena telah membantu karyawan dengan membuat kebijakan yang dapat menunjang terjadinya keseimbangan antara kehidupan pribadi dan pekerjaan sehingga menimbulkan rasa ingin membalas atas kebaikan yang telah di lakukan dengan cara berkomitmen terhadap organisasi (Cropanzano \& Mitchell, 2005). Karyawan perlu untuk terlebih dahulu beradaptasi dengan sistem yang diberikan oleh organisasi untuk mencapai keseimbangan antara pekerjaan dan kehidupan pribadi, ketika keseimbangan tersebut tercapai maka akan dapat terbentuk komitmen dalam diri karyawan.

Pada konteks industri perhotelan, jam kerja yang berlangsung sampai saat ini adalah 24 jam penuh melalui shift kerja. Meski demikian jadwal shift kerja yang ditetapkan oleh pihak hotel tentu dapat dirundingkan penetapannya. Ketika karyawan tertentu merasa tidak mampu untuk mengikuti jadwal yang ditetapkan, organisasi dapat memberikan kelonggaran bagi karyawan tersebut untuk dapat bertukar jadwal dengan rekan kerja lainnya. Dalam hal ini pihak hotel berusaha mendukung karyawannya untuk menciptakan keseimbangan antara jam kerja dengan kehidupan pribadi. Ketika karyawan merasakan bahwa organisasi memberikan kesempatan bagi karyawan untuk beradaptasi dengan jadwal yang dibuat maka karyawan akan merasa bahwa organisasi bersikap lebih fleksibel, dan hal inilah yang akan membuat karyawan merasa dipedulikan. Perasaan 
inilah yang kemudian akan menimbulkan komitmen terhadap tempat kerjanya khususnya komitmen afeksi.

Komitmen afektif pada penelitian ini juga terbukti memberikan dampak terhadap peningkatan kinerja karyawan. Hal ini sejalan dengan studi terdahulu yang dilakukan oleh Ramli (2019); Dinc (2017); dan Saygan (2011). Ketika karyawan memiliki komitmen afektif yang tinggi, berarti karyawan merasa cocok dengan organisasi yang membuat karyawan merasa nyaman untuk berada dalam organisasi tersebut. Oleh karena itu, karyawan akan menghasilkan respon yang positif seperti menunjukkan kinerja yang baik dengan mengerahkan semua kemampuannya dan usaha yang sangat tinggi demi mencapai tujuan organisasi (Krishnan et al., 2018). Dalam penelitian ini diketahui bahwa karyawan yang merasa mengalami keseimbangan antara kehidupan pribadi dan pekerjaan akibat kebijakan yang ditetapkan oleh organisasi, dapat meningkatkan komitmennya terhadap organisasi yang kemudian dapat memberikan hasil kerja yang lebih maksimal dan memberikan nilai positif bagi pencapaian tujuan organisasi.

\section{SIMPULAN DAN SARAN}

Penelitian ini memberikan beberapa kesimpulan empiris atas fenomena yang diteliti antara lain diketahui bahwa work life balance berpengaruh tidak signifikan terhadap kinerja karyawan; kemudian work life balance berpengaruh secara signifikan terhadap komitmen afektif; dan terakhir komitmen afektif berpengaruh signifikan terhadap kinerja karyawan.

Beberapa saran yang dapat diajukan untuk penelitian selanjutnya adalah menambahkan variabel yang masih relevan dengan work life balance misalnya stres kerja, work overload, yang secara khusus terkait dengan kerja shift pada industri perhotelan. Terkait hasil penelitian disarankan untuk memberikan tambahan pembuktian empiris khususnya terkait peran work life balance terhadap kinerja karyawan yang terbukti tidak signifikan, sebagai tambahan pengetahuan dan penjelasan atas fenomena hubungan diantara kedua variabel tersebut.

\section{DAFTAR REFERENSI}

Arif, B., \& Farooqi, Y. A. (2014). Impact of work life balance on job satisfaction and organizational commitment among university teachers: A case study of University of Gujrat, Pakistan. Internation journal of multidisciplinary sciences and engineering, 5(9), 24-29.
Aslam, M. (2015). Influence of work life balance on employees performance: moderated by transactional leadership. Journal of Resources Development and Management, 10(4), 24-29.

Chaitra, R., Kumar, A., \& Murthy, R. (2016). A study on work life balance of the employees at bosch Itd, bangalore. International Journal of Social Research, 12(3), 61-68.

Cropanzano, R., \& Mitchell, M. S. (2005). Social exchange theory: An interdisciplinary review. Journal of management, 31(6), 874-900.

Dinc, M. S. (2017). Organizational commitment components and job performance: Mediating role of job satisfaction. Pakistan Journal of Commerce and Social Sciences (PJCSS), 11(3), 773-789.

Fidyani, L., \& Prasetya, A. (2018). Pengaruh Work Life Balance Terhadap Kesuksesan Karier Karyawan (Studi Pada Perawat Rumah Sakit Umum Daerah Kabupaten Sidoarjo). Jurnal Administrasi Bisnis, 61(2), 79-88.

Francis, V., Lingard, H., \& Gibson, A. (2006). A qualitative study of work-life experiences in the public and private sectors of the Australian construction industry, Final Report. Brisbane, Construction Industry Institute Australia, 142(2), 1-32.

Guest, D. E. (2002). Perspectives on the study of worklife balance. Social Science Information,41(2), 255-279.

Hair, J. F., Sarstedt, M., Ringle, C. M., \& Mena, J. A. (2012). An assessment of the use of partial least squares structural equation modeling in marketing research. Journal of the academy of marketing science, 40(3), 414-433.

Jainudin, Ikhram, A.A., \& Hardiyono. (2019). Pengaruh work life balance terhadap burnout dan kepuasan kerja karyawan (studi kasus pada perusahaan listrik negara area makassar selatan). Management Development and Applied Research Journal, 1(2), 27-34.

Kim, H. K. (2014). Work-life balance and employees' performance: The mediating role of affective commitment. Global Businessand Management Research, 6(1), 37-51.

Krishnan, R., Loon, K. W., \& Tan, N. Z. (2018). The effects of job satisfaction and work-life balance on employee task performance. International Journal of Academic Research in Business and Social Sciences, 8(3), 652-662.

Lee, H. J., \& Reade, C. (2018). The role of Yin-Yang leadership and cosmopolitan followership in fostering employee commitment in China. Cross Cultural \& Strategic Management, 25(2), 276298. 
Lin, S., Lamond, D., Yang, C. L., \& Hwang, M. (2014). Personality traits and simultaneous reciprocal influences between job performance and job satisfaction. Chinese Management Studies, 8(1), 6-26.

Lingard, H. C., Francis, V., \& Turner, M. (2010). Work-family enrichment in the Australian construction industry: Implications for job design. Construction Management and Economics, 28(5), 467-480.

Lingard, H., \& Francis, V. (2004). The work-life experiences of office and site-based employees in the Australian construction industry. Construction Management and Economics, 22(9), 991-1002.

Lingard, H., Brown, K., Bradley, L., Bailey, C., \& Townsend, K. (2007). Improving employees' work-life balance in the construction industry: Project alliance case study. Journal of construction engineering and management, 133(10), 807-815.

Mendis, M. D. V. S., \& Weerakkody, W. A. S. (2017). The impact of work life balance on employee performance with reference to telecommunication industry in Sri Lanka: a mediation model. Kelaniya Journal of Human Resource Management, 12(1), 72-100.

Meyer, J. P., \& Allen, N. J. (1991). A three-component conceptualization of organizational commitment. Human resource management review, 1(1), 6189.

Mohanty, K., \& Mohanty, S. (2014). An empirical study on the employee perception on work-life balance in hotel industry with special reference to Odisha. Journal of Tourism and Hospitality Management, 2(2), 65-81.

Oyewobi, L. O., Oke, A. E., Adeneye, T. D., \& Jimoh, R. A. (2019). Influence of organizational commitment on work-life balance and organizational performance of female construction professionals. Engineering, Construction and Architectural Management, 9(3), 1-22.

Ramli, A. H. (2019). Organizational commitment and employee performance at distributor companies. Business and Entrepreneurial Review, 17(2), 121-134.

Rene, R., \& Wahyuni, S. (2018). Pengaruh work life balance terhadap komitmen organisasi, kepuasan kerja, dan motivasi kerja terhadap kinerja individu pada karyawan perusahaan asuransi di jakarta. Jurnal Manajemen dan Bisnis Sriwijaya, 16(1), 53-63.

Riffay, A. (2019). Pengaruh keseimbangan kehidupan kerja (work life balance) dan kepuasan kerja terhadap komitmen organisasi guru sd negeri di kecamatan kota masohi. Jurnal Ilmiah Wahana Pendidikan, 5(3), 39-47.

Rini, K. G. G. P., \& Indrawati, K. R. (2019). Hubungan Antara Work-Life Balance dengan Komitmen Organisasi Perempuan Bali yang Bekerja pada Sektor Formal. Jurnal Psikologi Udayana, 6(1), 153-164.

Sabijono, K.P., Saerang, D.P., \& Tumewu, F. (2017). A qualitative study of employees work life balance and organizational commitment at $\mathrm{pt}$ bank mandiri (persero) tbk manado. Jurnal Manajemen Bisnis dan Akuntansi, 5(2), 29482957.

Sayğan, F. N. (2011). Relationship between affective commitment and organizational silence: A conceptual discussion. International journal of social sciences and humanity studies, 3(2), 219227.

Simmons, S. (2012). Striving for work-life balance. AJN The American Journal of Nursing, 112(1), 25-26.

Sivaraman, N. (2016). Work-Life-Balance: Consequences and Solutions. International Journal of Advanced Scientific Research \& Development (IJASRD), 3(1), 52-58.

Sturges, J., \& Guest, D. (2004). Working to live or living to work? Work/life balance early in the career. Human Resource Management Journal, 14(4), 5-20.

Sukamto, H., Junarto, Y., Kaihatu, T. S., \& Kartika, E. W. (2014). Analisa pengaruh komitmen afektif, komitmen normatif, dan komitmen berkelanjutan terhadap turnover intention di dragon star surabaya. Jurnal Hospitality dan Manajemen Jasa, 2(2), 466-478.

Suresh, D., \& Begum, M.F. (2018). A study on work life balance in hotel employees, trichirappalli district. Research Review International Journal of Multidisciplinary, 11(1), 84-88.

Van Scotter, J., Motowidlo, S. J., \& Cross, T. C. (2000). Effects of task performance and contextual performance on systemic rewards. Journal of applied psychology, 85(4), 526-535. 